\title{
Ansatte i helsehus må ha kompetanse i psykisk helsearbeid
}

Det tverrfaglige prosjektet «Kropp og sjel» førte til at ansatte og studenter i helsehus ble tryggere i møte med pasienter med sammensatte helseutfordringer.

\section{Hanne Morttjernet}

Universitetslektor

Oslomet

\section{Kajsa Annika Borg Diesen}

\section{Fagkonsulent}

Senter for fagutvikling og forskning, Utviklingssenter for sykehjem og hjemmetjenester,

Oslo kommune

\section{Tore Bonsaksen}

\section{Professor}

Seksjon for psykisk helse og rehabilitering, Fakultet for helse- og sosialvitenskap, Høgskolen i Innlandet, Elverum

\section{Hovedbudskap}


I denne artikkelen vil vi dele erfaringene fra «Kropp og sjel», et tverrprofesjonelt kompetansehevingsprosjekt i psykisk helsearbeid for helsepersonell og studenter i helsehus i Oslo kommune. Ansatte i helsehusene beskrev at de var usikre i møte med pasienter som hadde psykiske plager i tillegg til somatiske helseplager, og enkelte hadde også rusproblemer. De som deltok i «Kropp og sjel», følte seg tryggere og mer kompetente i møte med disse pasientene enn før oppstarten av prosjektet.

Hensikten med «Kropp og sjel» var å bidra til et tverrfaglig kompetanseløft for studenter og ansatte knyttet til temaene samhandling, kommunikasjon og relasjoner i møte med pasienter med psykiske lidelser og rusproblemer.

Målet var at kompetanseløftet skulle gi bedre helsetjenester for pasientene, bedre tverrfaglig samarbeid og et tryggere arbeidsmiljø for de ansatte. I tillegg var målet at prosjektet skulle bidra til etablering av nye praksisplasser innen psykisk helsearbeid og rus for bachelorstudenter i sykepleie.

Et uttalt helsepolitisk mål er at kvaliteten for sykepleierstudenter i praksis skal være $h \varnothing y$, da 50 prosent av studiet er praksisstudier (1).

\section{Flere hadde problemer med rus og psykisk helse}

Som en følge av samhandlingsreformen, som trådte kraft i 2012 (2), samlet Oslo kommune i 2015 korttidsavdelinger og rehabiliteringsavdelinger fra alle byens sykehjem i fire helsehus.

Hensikten med å etablere helsehusene var å samle fagkompetanse, redusere liggetid og tilrettelegge for at pasientene kunne reise hjem med videre oppfølging fra hjemmetjenesten, eller alternativt få oppfølging eller behandling på andre institusjoner.

Flere yngre pasienter ble innlagt med rehabiliteringsbehov og hadde samtidig aktive psykiske lidelser og rusproblemer. Det ga personalet mange nye utfordringer. Pasientene var i hovedsak eldre, men enkelte var fra 25 år og oppover.

\section{Målgruppen skulle utvikle et bedre klinisk blikk}

Samhandlingsreformen (2) medførte at ansatte og studenter møtte større utfordringer med tanke på å ivareta pasienter med psykiske lidelser i tillegg til fysiske sykdommer og rehabiliteringsbehov. 
Det medførte et behov for kompetanseheving i psykisk helsearbeid. Hensikten var at målgruppen for prosjektet skulle få «psykisk helse-briller» på, samt å utvikle et bedre klinisk blikk for å se kropp og sjel i sammenheng.

\section{«Et av tiltakene for å møte behovet for kompetanseheving var prosjektet 'Kropp og sjel'.»}

Et av tiltakene for å møte behovet for kompetanseheving var «Kropp og sjel», et samarbeidsprosjekt mellom avdeling for kvalitet og utvikling i Sykehjemsetaten, Senter for fagutvikling og forskning / Utviklingssenter for sykehjem og hjemmetjenester (SFF/USHT Oslo) og ergoterapi-, sykepleie- og fysioterapiutdanningene ved Oslomet.

Prosjektet ble gjennomført fra 2015 til 2017 og ble støttet med samhandlingsmidler fra Høgskolen i Oslo og Akershus (nå: Oslomet).

\section{Metode}

Vi arrangerte fokusgruppeintervju 1 før prosjektoppstarten, der vi intervjuet sjuåtte ansatte i helsehuset om deres egen opplevelse av kompetanse i klinisk psykisk helsearbeid.

I løpet av prosjektperioden arrangerte vi fire tverrfaglige fagseminarer, som var basert på læringsbehovene fra de ansatte fra fokusgruppeintervjuet.

Foredragsholderne representerte ulike faggrupper og kom fra spesialisthelsetjenesten, Oslomet og kommunen.

Parallelt med fagseminarene gjennomførte vi tverrfaglige gruppeveiledninger med ansatte og studenter. I tillegg var det ordinær studentveiledning på Oslomet. Gruppeveilederne kom fra Oslo kommune ved SFF/USHT og fra Oslomets institutter for sykepleie, ergoterapi og fysioterapi.

Som et ledd i evalueringen av kompetansehevingsprosjektet gjennomførte vi fokusgruppeintervju 2 etter at prosjektet var avsluttet. Temaet var betydningen av aktivitetene i prosjektet for medarbeiderne.

\section{Etikk}

I forbindelse med fokusgruppeintervjuene innhentet vi godkjenning fra Norsk senter for forskningsdata (NSD nummer 48856).

Alle deltakerne i prosjektets fokusgruppeintervjuer fikk informasjon om at det var frivillig å delta, og at de kunne trekke seg uten konsekvenser. De som valgte å delta, fylte ut informert skriftlig samtykke. Alle persondata fra prosjektet er anonymisert. 


\section{De ansatte hadde behov for mer kompetanse}

I fokusgruppeintervjuet innledningsvis i prosjektperioden kartla vi de ansattes behov for kompetanseheving. Her kom det frem at de hadde behov for kompetanse om psykisk sykdom, miljøterapi og behandlingstilnærming til personer med psykose og uro, spesielt ved risiko for utagering.

Andre problemstillinger deltakerne nevnte, var hvordan man skulle jobbe med pasienter som ikke var motivert for å trene, noe som påvirket rehabilitering og utskrivingsprosessen til deres eget hjem eller boligen/institusjonen.

Fagseminarene og veiledningene var basert på behovene for kompetanseheving som kom frem i fokusgruppe 1. Kunnskap om komorbiditet, for eksempel hvordan psykose eller angst og depresjon kan påvirke pasientens funksjon og motivasjon for å rehabilitere en somatisk tilstand, var etterspurt.

En av de ansatte hadde innledningsvis flere grunnleggende spørsmål: «Hvordan skal jeg klare å hjelpe noen når jeg ikke klarer å nå personen? Hvordan skal jeg oppføre meg? Kan jeg gå inn i deres verden?»

\section{Lovverket skiller ikke mellom fysisk og psykisk helse}

Som pasient har man rett til nødvendig helsehjelp fra kommunens helse- og omsorgstjeneste. Det er en forutsetning at kommunen er i stand til å gi forsvarlig hjelp. Ellers må pasienten henvises videre til spesialisthelsetjenesten (3).

Lovverket skiller ikke mellom fysiske og psykiske helseproblemer. Det var derfor en motivasjon for en større satsing på kompetanseheving innen psykisk helsearbeid.

Kunnskap om hvor helsearbeidere kan henvende seg for å få bistand til å håndtere pasienters psykiske vansker, kom frem som et viktig tema: «Når jeg jobber med pasienter som har utfordringer med sin stomi, med kreftbehandling eller palliasjon, så vet jeg hvor jeg henvender meg, men ikke når det gjelder psykiatri.»

\section{«De ansatte var mer nysgjerrige og lurte på hva som kunne være grunnen til atferd som de observerte.»}

Etter at prosjektet var avsluttet, arrangerte vi et nytt fokusgruppeintervju. Der kom det frem at de ansatte så på seg selv som mer observante. De oppdaget tegn på depresjon og angst og viste større interesse og forståelse for pasienter med psykose. 
De ansatte var mer nysgjerrige og lurte på hva som kunne være grunnen til atferd som de observerte. For eksempel nevnte de at de var mer observante på tegn til initiativløshet, tilbaketrekning, irritasjon og mistenksomhet hos pasientene.

De ansatte tenkte nå på mulige underliggende psykiske årsaker i samhandling med pasientene. De beskrev en større forstålse for psykiske utfordringer og sammenhenger mellom kroppslige og psykiske plager.

\section{Ansatte var mer faglig kompetente etter prosjektet}

Ansatte ga i fokusgruppeintervju 2 uttrykk for at de så annerledes på pasientene etter prosjektperioden. De så på seg selv som mer faglig kompetente og hadde større grad av faglig trygghet og selvtillit enn før prosjektet.

En av de ansatte beskrev det slik: «Før tenkte jeg: Å nei, psykisk syk! Nå tenker vi ikke over det i det hele tatt, nå er det bare en del av pasientens problemer.»

Flere av de ansatte fremhevet nytteverdien av å se animasjonsfilmer på fagseminarene. I filmene var det beskrivelser av hvordan personer opplevde å være i en psykose. Det påvirket personalets forståelse for pasientens opplevelse, og en ansatt uttrykte seg slik:

«Det var den verdenen. At det virkelig var sånn de opplever det? Jeg har jo skjønt det, men å se det i bilder, herregud ... at det kunne være virkeligheten deres !?!»

\section{Mer tid var en nøkkel for å lykkes}

De ansatte beskrev i fokusgruppeintervju 2 hvordan tid, strukturer, rammer og en oppgavepreget organisering påvirket klinisk daglig praksis og tilbudet til pasientene. De beskrev et dilemma når de hadde ansvar for mange pasienter. Tiden de brukte til relasjonsbygging med en pasient, kunne føre til at andre pasienter måtte vente på hjelp.

Personalet mente at mer tid var en nøkkel for å lykkes. De formidlet at arbeidsrutinene i mindre grad var lagt til rette for tidkrevende relasjonsarbeid, at organiseringen av de daglige gjøremålene og strukturen i avdelingen var mer oppgave- og prosedyreorientert, og at bestillingen fra bydelene som disponerte korttidsplassene, ofte var av somatisk karakter.

\section{«I fokusgruppeintervjuet kom det frem at det er tidkrevende å oppfordre til trening når pasienten ikke er motivert.»}


En utfordring dreide seg derfor om hvordan den $\varnothing$ kte kompetansen i relasjonsarbeid kunne brukes i en oppgavepreget kontekst med mye oppmerksomhet på fysisk funksjon og somatiske problemstillinger.

I fokusgruppeintervjuet kom det frem at det er tidkrevende å oppfordre til trening når pasienten ikke er motivert. En av de ansatte fortalte: «De (pasientene) kan bli fort lei seg, de gråter, de avviser folk og personalet, nekter å få hjelp. Det er bare å gi dem tid, faktisk.»

\section{De ansatte etterlyste klare retningslinjer}

De ansatte beskrev betydningen av å skape en relasjon, men at de ikke hadde den tiden som var nødvendig for å følge opp og bygge opp tillit hos pasienter som var redde eller sinte.

De etterlyste klare retningslinjer for praksis innenfor psykisk helsearbeid og mer kunnskap, slik at de kunne handle kunnskapsbasert og utføre praksis på samme måte som i somatikken. De uttrykte et ønske om klare prosedyrer - noe som kanskje kan utfordre relasjonsarbeidets krav om fleksibilitet og skjønn.

Erfaringene fra fokusgruppe 2 viste at den oppgavefokuserte driften i avdelingen etter at prosjektet var over, ble utfordret etter kompetansehevingen. De ansatte fokuserte på tidsbruk i relasjonsarbeid i konkurranse med tid til de praktiske oppgavene.

De diskuterte hvordan kunnskap om godt relasjonsarbeid kunne føre til bedre ivaretakelse av pasienten og gi større handlingskompetanse innen psykisk helsearbeid.

Noe av tanken med å ha «psykisk helse-briller» på var å kunne utvikle et bedre klinisk blikk for å se kropp og sjel i sammenheng. Det kan bidra til at rehabiliteringstiden forkortes og psykiske utfordringer forebygges og ivaretas.

\section{Veiledningene ga studentene bedre innsikt}

I prosjektets fellesveiledninger diskuterte deltakerne de ulike profesjonenes tilnærminger og perspektiver. Personer med ulik fagbakgrunn ga veiledning om hvordan sykepleiere, ergoterapeuter, fysioterapeuter og helsefagarbeidere kommuniserer med pasienten, og hvilke metoder de bruker (4-6).

I enkelte veiledningstimer var det veiledere fra flere utdanninger, noe som deltakerne fikk stort utbytte av. Deltakerne ga uttrykk for at veiledningene ga dem bedre innsikt i og forståelse for andre profesjoners kompetanse. 


\section{«I enkelte veiledningstimer var det veiledere fra flere utdanninger, noe som deltakerne fikk stort utbytte av.»}

Det bidro til at de fikk lavere terskel for å kontakte andre yrkesgrupper. Fagseminarene inneholdt temaer som tok utgangspunkt i de ulike profesjonenes perspektiver, hvilket førte til at helsepersonellet uansett profesjon kjente seg godt igjen i de ulike forelesningene.

\section{Det tverrfaglige perspektivet var positivt}

De ansatte evaluerte det tverrfaglige perspektivet i veiledninger og fagseminarer positivt. A verdsette det tverrfaglige krevde imidlertid refleksjon, slik en av de ansatte beskrev det:

«[...] du legger ikke merke til at det er tverrfaglig før du må sette deg tilbake og se. Studentene gjør jo det. Så det synes jeg var kjempemorsomt. Hvordan det skapte en behandlingshelhet for pasienten $[. .]$.

Det var gode tilbakemeldinger på at foreleserne kom fra ulike instanser, som spesialisthelsetjenesten, Oslomet, kommunens ulike tilbud og ideelle organisasjoner i tillegg til brukererfaringer. Det førte til en gjensidig utveksling av erfaringer, noe som ga foreleserne $\varnothing \mathrm{kt}$ forståelse for hverdagen $\mathrm{i}$ helsehusene.

I veiledningen kom det frem at sykepleierstudentenes mulighet til å konsentrere seg om den enkelte pasienten førte til at de kunne sette opp en behandlingsplan. Det viste seg å være så nyttig at den ble brukt på nytt når pasienten kom inn igjen på rullerende opphold, eller som utgangspunkt for andre pasienter med liknende problematikk.

Det bidro til forutsigbarhet for pasienter som kom tilbake til nye opphold på helsehuset, og det var tidsbesparende for personalet.

\section{Personalet merket en endring hos studentene}

I begynnelsen av prosjektet var det utfordrende for personalet å skulle veilede sykepleiestudenter fra andre studieår med praksis i psykisk helsearbeid og rus. Personalet var vant til å veilede studenter i første studieår, som skulle lære grunnleggende sykepleie.

Etter at studentene hadde vært der i et par perioder, opplevde personalet en endring: Studentene ble mer bevisst på det psykiske helsearbeidet i avdelingen. Etter at prosjektet var ferdig, valgte avdelingen å avvente tilbud om praksisplasser innen psykisk helse fordi rammene fortsatt var uendret. 
Enkelte praksisveiledere følte at det var krevende å veilede i psykisk helsearbeid når de ikke hadde formell spesialistkompetanse. Fysioterapi- og ergoterapistudentene hadde allerede etablerte plasser innenfor psykisk helse og rus på andre praksisplasser.

\section{Konklusjon}

Funn fra fokusgruppeintervju 1 før prosjektstarten viste at personalet $\varnothing$ nsket større kompetanse i psykisk helsearbeid. De ønsket klare og konkrete prosedyrer.

Tiden de skulle bruke på for eksempel relasjonsarbeid, konkurrerte med tiden til praktiske oppgaver, og det utfordret den oppgavefokuserte driften i avdelingen. I fokusgruppe 2 etter prosjektet viste det seg at de ansatte opplevde $\varnothing \mathbf{k t}$ kompetanse og større bevissthet om allerede eksisterende kompetanse på fagfeltet.

De ansatte så på seg selv som mer observante. De la merke til tegn på depresjon og angst, viste større interesse og forståelse for pasienter med psykose og så sammenhenger mellom kroppslige og psykiske plager. De nærmet seg pasientene på en annen måte og brukte i større grad behandlingsplaner med vekt på psykisk helse i tillegg til de somatiske problemstillingene.

Det var også positive tilbakemeldinger på det tverrfaglige perspektivet $\mathrm{i}$ veiledninger og fagseminarer. Målet om at prosjektet skulle bidra til å etablere nye praksisplasser i psykisk helsearbeid og rus for sykepleie-, ergoterapi- og fysioterapistudenter, ble ikke oppfylt i prosjekttiden.

Det kan likevel se ut som at et lokalbasert bottom-up-prosjekt som «Kropp og sjel» kan bidra til viktig kompetanseheving blant ansatte i omstillingsprosesser, for eksempel omorganisering fra sykehjem til helsehus, noe som innebærer nye arbeidsoppgaver.

\section{Referanser}

1. Hovdhaugen E, Nesje K, Reegård K. Hvordan sikre at sykepleiestudentene oppnår læringsutbytter i praksisstudiene: jakten på gode eksempler. Oslo: Nordisk institutt for studier av innovasjon, forskning og utdanning (NIFU); 2021. Rapport 2021-1. Tilgjengelig fra: https://nifu.brage.unit.no/nifu-xmlui/handle/11250/2725062 (nedlastet 14.10.2021).

2. St.meld. nr. 47 (2008-09). Samhandlingsreformen - rett behandling - på rett sted - til rett tid. Oslo: Helse- og omsorgsdepartementet; 2009. Tilgjengelig fra: https://www.regjeringen.no/no/dokumenter/stmeld-nr-47-2008-2009-/id567201/ (nedlastet 14.10.2021). 
3. Lov 1. januar $2001 \mathrm{nr} .63$ om pasientrettigheter (pasientrettighetsloven). Tilgjengelig fra: https://lovdata.no/dokument/NL/lov/1999-07-02-63 (nedlastet 14.10.2021).

4. Høgskolen i Oslo og Akershus. Programplan for bachelorstudiet i ergoterapi. Oslo: Høgskolen i Oslo og Akershus; 2015. Tilgjengelig fra:

https://docplayer.me/2696332-Programplan-for-bachelorstudiet-i-ergoterapi.html (nedlastet 14.10.2021).

5. Høgskolen i Oslo og Akershus. Programplan for bachelorstudiet i fysioterapi. Oslo: Høgskolen i Oslo og Akershus; 2014. Tilgjengelig fra:

https://docplayer.me/16693314-Programplan-for-bachelorstudium-i-fysioterapistudieretning-mensendieck.html (nedlastet 14.10.2021).

6. Høgskolen i Oslo og Akershus. Programplan for bachelorstudiet i sykepleie. Oslo: Høgskolen i Oslo og Akershus; 2014. Tilgjengelig fra: https://docplayer.me/11263445-Programplan-bachelorstudium-i-sykepleie.html (nedlastet 14.10.2021).

FAGUTVIKLING

\section{Bruk av rusmidler er}

\section{utbredt hos personer med psykoselidelse}

Når helsepersonell kartlegger pasientenes sykdom, er det nødvendig å spørre hver enkelt om deres bruk av rusmidler og hvilken funksjon bruken har.

Kvalitativ studie

Psykisk lidelse

Stoffmisbruk

Rus

Rusmiddel

Profesjonelle helsearbeidere spør sjelden hvorfor og hvordan pasienter med alvorlige psykiske lidelser bruker rusmidler når det er grunn til å tro at de gjør det.

I denne artikkelen, som bygger på mitt doktorgradsarbeid fra 2015, redegjør jeg for hvilke erfaringer en gruppe pasienter med psykoselidelse og samtidig ruslidelse i opps $\varnothing$ kende behandling har med rusmidler. 


\section{Vi vet lite om psykoselidelse og rusbruk}

Personer med alvorlig psykisk lidelse er mer tilbøyelige til å bruke rusmidler enn andre $(1,2)$. Internasjonal forskning viser at disse personene skårer dårligere enn andre på viktige levekårsindekser (3), er vanskelige å få i behandling og har en tendens til å droppe ut av behandlingen (4).

Behandling av personer med samtidig ruslidelse og psykisk lidelse (ROP-lidelse) gjøres både i psykisk helsevern, i tverrfaglig spesialisert rusbehandling (TSB) og til en viss grad i kommunene.

Selv om vi vet mye om de skadelige virkningene av rusmidler, finnes det også forskning som viser at visse rusmidler i et gitt omfang har en positiv effekt for brukerne dersom de ikke bruker det for ofte, og ikke bruker for sterke rusmidler (5).

Men vi vet fortsatt lite om hvorfor og hvordan personer med psykoselidelse ruser seg. Er det tilfeldig hvilke rusmidler de bruker, i hvilke mengder, og hvor ofte de bruker det? Og er det slik at personer med en spesifikk psykiatrisk diagnose foretrekker bestemte typer rusmidler fremfor andre?

\section{Stadig flere får behandling i ACT-team}

Som en del av regjeringens satsing på samhandling i psykisk helsefeltet bevilget Helse- og omsorgsdepartementet gjennom statsbudsjettet for 2010 midler til opprettelse og drift av Assertive Community Treatment-team (ACT-team) i Norge.

I løpet av perioden 2008-2012 startet departementet opp 14 slike team. Parallelt startet en forskningsbasert evaluering av disse teamene. Evalueringen viste at de som var inkludert i ACT, hadde redusert behov for innleggelser på sykehus og ble i mindre grad enn ved annen behandling underlagt tvangsvedtak (6).

I de påfølgende årene har stadig flere med ROP-lidelser fătt behandling og oppfølging i ACT-team eller Flexible Assertive Community Treatment-team (FACT-team), som har blitt et satsingsområde for helsemyndighetene.

\section{De fleste hadde en psykisk lidelse først}

Denne studien hadde et deskriptivt og eksplorativt design med en fenomenologisk tilnærming. Den handlet om forskningsdeltakernes livserfaringer og er beskrevet i tidligere arbeider (7-9). 
Jeg gjennomførte til sammen 20 individuelle intervjuer med et utvalg av brukere ( $\mathrm{n}$ = 11) med ROP-lidelse inkludert norske ACT-team. Inklusjonskriteriene var oppnådd bedring på områdene livskvalitet og/eller funksjonsnivå og/eller rusmiddelbruk etter minimum tolv måneder i behandling.

\section{«Flesteparten brukte flere typer rusmidler, men hadde ikke utviklet avhengighet.»}

Deltakerne var ni menn og to kvinner i alderen 27-63 år. De fleste var diagnostisert med schizofreni eller schizoaffektiv lidelse, men det var også deltakere med bipolar og uspesifisert psykoselidelse. For de fleste av deltakerne hadde den psykiske lidelsen vært fremtredende før de begynte med rusmidler.

Flesteparten brukte flere typer rusmidler, men hadde ikke utviklet avhengighet. De rusmidlene som deltakerne benyttet hyppigst, var cannabis og amfetamin. Også alkohol ble benyttet, men i noe mindre grad.

\section{Alle deltakerne bodde alene}

De fleste ruset seg tre-fire ganger per uke, ofte i sammenheng med $\varnothing$ kte symptomer på den psykiske lidelsen. Fire av deltakerne hadde sluttet helt med rusmidler.

Alle bodde alene, de fleste i en bolig de leide gjennom kommunen, mens to av deltakerne eide leiligheten de bodde i. Fire av deltakerne var i lønnet arbeid, enten i praksisplass gjennom Nav eller annet tilrettelagt tilbud. De $\varnothing$ vrige var helt eller delvis uføretrygdet.

Jeg gjennomførte individuelle intervjuer hjemme hos deltakerne eller i et egnet møterom i ACT-teamets lokaler. Intervjuene hadde en varighet på om lag en time. Deretter analyserte jeg den transkriberte teksten fra intervjuene med systematisk tekstkondensering (10).

\section{Forholdet til rus var motsetningsfylt}

Deltakerne i studien hadde et motsetningsfylt forhold til rusmidler. På den ene siden ga rusmidler dem positive opplevelser og var en måte å mestre den psykiske lidelsen på.

På den andre siden hadde de fleste også negative erfaringer med bruk av rusmidler og hadde etablert strategier for å kutte ut eller redusere bruken. 
Hovedtemaene og undertemaene jeg kom frem til i studien, kan vi se i figur 1.

Figur 1. Hovedtemaer og undertemaer som kom frem under analysen.
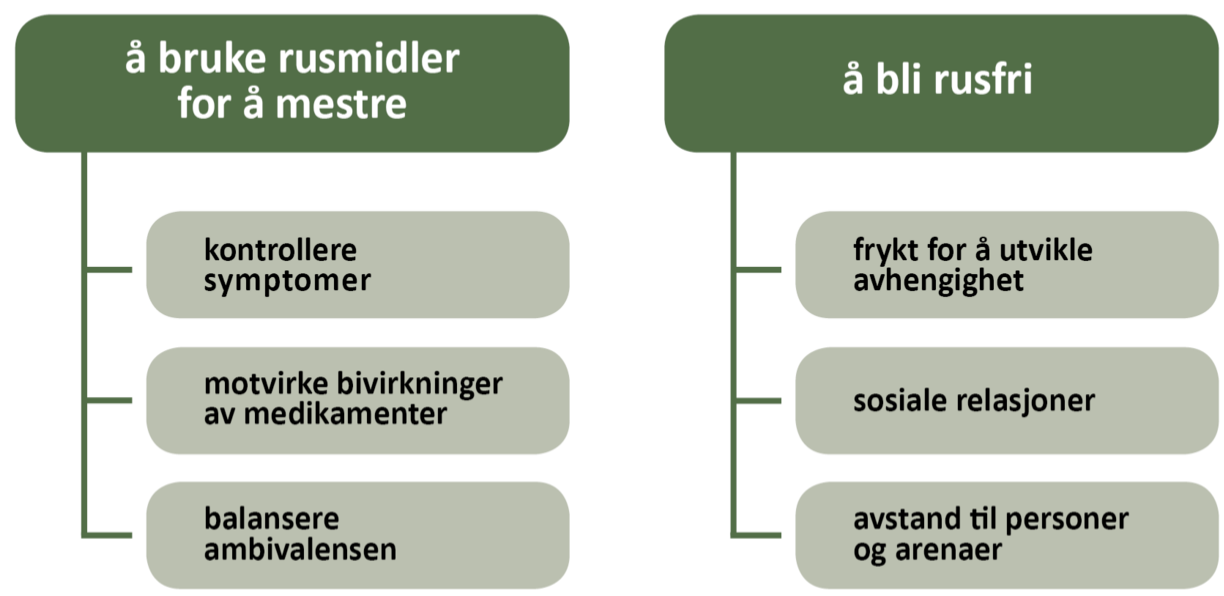

\section{Alkohol dempet angst og depresjon}

Jeg unders $\varnothing$ kte hvordan ulike emosjonelle tilstander ble påvirket av rusmidler. Noen av deltakerne som brukte eller hadde brukt alkohol regelmessig, forklarte at hensikten med alkoholbruken var å dempe angst og depresjon og ta en pause fra alt som var vanskelig i livet.

\section{«Noen mente at alkohol var mindre skadelig enn illegale rusmidler.»}

Noen mente at alkohol var mindre skadelig enn illegale rusmidler. Andre uttrykte en forkjærlighet for cannabis eller amfetamin og omtalte alkohol i negative ordelag ved at den ofte skaper større problemer både for enkeltindivider og på samfunnsnivå.

Årsakene de oppga for å bruke rusmidler, var at det både var en måte å unnslippe ubehagelige tilstander på og en mulighet til å fokusere på noe annet. De forklarte dette ved hjelp av uttrykk som pause, avbrudd eller flukt.

Noen hadde utviklet strategier for å innarbeide slike «timeouts» i sin hverdag, mens det skjedde mer vilkårlig for andre.

\section{Cannabisbruk mildnet indre stemmer}

En av deltakerne (mann, 45 år) var diagnostisert med paranoid schizofreni og hadde brukt alkohol i mange år som en bevisst strategi for å håndtere angst og depressive tanker: 
«Det går en periode på 24 dager, og så kommer det $12 \varnothing 1$ som stopper det vanskelige [...] som en pause. Og det er å være et annet sted fordi du er full. Altså, da er jeg er fornøyd når jeg begynner på blanke ark og fortsetter 24 dager til. Og så kommer det tolv $\varnothing 1$ [...] og så går jo livet sånn, da. Så får du jo kanskje en takk av Gud eller et eller annet fordi du har greid det.»

Flere av deltakerne anså bruk av cannabis som en måte å håndtere indre stemmer på. I de fleste tilfellene kunne cannabisbruk mildne påvirkningen av høye og dominerende eller befalende stemmer.

\section{Amfetamin kunne regulere maniske faser}

Bruken av amfetamin så ut til å ha mange funksjoner. Et anvendelsesområde var å regulere eller initiere maniske faser ved bipolar lidelse. De av deltakerne dette gjaldt, forklarte at mani som var fremskyndet av amfetamin, var lettere å håndtere enn andre maniske episoder.

Fordi kontroll og stabilitet er viktig ved en bipolar lidelse, så de på amfetamin som et virkemiddel til å få hyppigere maniske faser, men at fasene var mindre dramatiske enn uten påvirkning av amfetamin.

Amfetamin syntes å være det foretrukne rusmiddelet når det gjaldt å håndtere plagsomme bivirkninger av antipsykotika. Vekt økning og medfølgende inaktivitet ble rapportert av mange av deltakerne som hadde brukt slike medikamenter.

\section{Antipsykotika gjorde deltakerne søvnige}

Flere av deltakerne uttrykte at de hadde behov for flere våkne dager siden antipsykotika gjorde dem sløve og søvnige. Det gjorde at de fikk en utpreget trang til å sove både dag og natt.

En av deltakerne (mann, 33 år) var diagnostisert med en schizoaffektiv lidelse og hadde brukt ulike antipsykotika i en årrekke:

«Jeg sto på Zyprexa, da fikk jeg angst og sov veldig mye. Det var da amfetaminbruken min begynte, så det har nok litt å gjøre med virkningen av antipsykotisk medisin. Jeg husker at jeg sov så mye... at jeg ønsket meg en dag eller en helg i måneden hvor jeg var våken.»

Deltakernes årsaker til å bruke rusmidler handlet også om ambivalens og tvil. Det samme rusmiddelet kunne ha forskjellige betydninger, virkninger og konsekvenser for ulike personer. 


\section{Bruk av rusmidler kunne skape problemer}

I et overordnet perspektiv anerkjente deltakerne den positive korttidsvirkningen av rusmidlene, men samtidig var de bevisst på skadelige langtidsvirkninger. Bruk av rusmidler kunne skape problemer, men likevel bidro de til at deltakerne fungerte bedre på mange arenaer.

Noen deltakere hadde erfart at spesielt amfetamin ga dem $\varnothing \mathrm{kt}$ energi og livslyst, men at de senere kunne få ubehagelige skjelvinger og oppleve betydelig nedstemthet.

\section{«Behovet for rusmidler syntes å være mindre påtrengende når symptomer på den psykiske lidelsen ikke var dominerende.»}

En deltaker (mann, 40 år) slet med overvekt og hadde brukt både amfetamin og cannabis for å gå ned i vekt. Han mente at det kunne være en hårfin balansegang. Han forklarte:

«Jeg husker at amfetamin gjorde at jeg gikk raskt ned i vekt, men etter hvert ble det ikke noe behagelig. Noen ganger har jeg brukt cannabis fordi det ikke har den umiddelbare effekten. Det er best å gjøre det gradvis. Jeg håper å stabilisere vekten på et akseptabelt nivå slik at jeg kan føle et slags velvære.»

Alle deltakerne brukte rusmidler for å håndtere episoder som oppsto på grunn av den psykiske lidelsen. Behovet for rusmidler syntes å være mindre påtrengende når symptomer på den psykiske lidelsen ikke var dominerende.

\section{Mange fryktet mer alvorlig rusmisbruk}

Rusmidlene kunne være til hjelp for å mestre noen plagsomme symptomer knyttet til deltakernes psykiske lidelse på kort sikt, men de fleste deltakerne innså at langtidsvirkningen av rusmidlene var negativ. De innså at det var viktig å kunne redusere eller slutte med rusmidler.

Mange uttrykte redsel for å utvikle toleranse overfor rusmidler og en mulig overgang til mer alvorlig rusmisbruk. De anså injisering av heroin som det farligste.

For de fleste deltakerne var en overgang fra rusmisbruk til avhengighet et symbol på en alvorlig forverring av selvbildet, noe som syntes å bidra til at noen hadde klart å kutte ut bruken av rusmidler. En av deltakerne (mann, 40 år), som for det meste hadde brukt alkohol, uttrykte seg slik: 
«Det beste er egentlig å holde seg unna alkoholen fordi hvis du har drukket i mange år, vil det fortsatt fremstå som en fristelse, både drikking og bruk av andre rusmidler. Du har et toleransenivå. Denne veien starter i det små, og etter hvert blir det heroin. Hasj ligger omtrent i midten. Så målet må være å ikke begi seg ut på den veien eller stake ut en annen kurs før det er for sent.»

\section{Deltakerne slet med avholdenhet}

Deltakerne fryktet å miste kontrollen på rusbruken og bli så påvirket at det forverret den psykiske lidelsen. Likevel ble perioder med avholdenhet opplevd som vanskelig for flere av dem fordi de ofte kjente på følelser som utilstrekkelighet og frykt.

Det syntes som om fraværet av rusen ledet til både positive og negative opplevelser. Alle deltakerne hadde erfart perioder med avholdenhet, men de fleste hadde ikke vært avhengig av rusmidler. Flertallet mente at de hadde et gjennomgående bedre funksjonsnivå når de holdt seg unna rusmidler.

\section{«Det å være $\mathrm{i}$ et forhold dempet behovet for rusmidler.»}

Relasjonelle faktorer var innbefattet i de fleste betingelsene for å klare å slutte med rusmidler. Aktiviteter med ulike formål og i ulike kontekster ble ofte nevnt og assosiert med forholdet til andre mennesker.

De fleste av deltakerne hadde erfart at å gjenopprette bånd med familie og nære venner og være i stand til å delta i dagliglivets aktiviteter var helt avgjørende.

Mange av årsakene deltakerne oppga for å bli rusfrie, handlet om betydningen av sosiale relasjoner og å unngå isolasjon og ensomhet. Argumentene var at man måtte være edru for å finne en partner, og at å være i et forhold dempet behovet for rusmidler.

\section{Deltakerne unngikk tidligere rusmiljøer}

De fleste av deltakerne fortalte om den negative innflytelsen fra tidligere rusmiljøer. For å unngå å vende tilbake til tidligere venner i rusmiljøene var det avgjørende for dem å motstå trangen til å gjenoppsøke disse miljøene.

Det fungerte ikke å innta en slags «mellomholdning». Det var enten-eller. En deltaker (mann, 43 år) hadde vært inn og ut av rusinstitusjoner mange ganger og hadde etter hvert utviklet en strategi for å stå imot rustrangen: 
«Jeg hadde ommøblert leiligheten, slik at det var annerledes å komme hjem den siste gangen, fordi jeg har opplevd å komme hjem på permisjon når alt i leiligheten minnet meg om mitt tidligere liv, og jeg ble fristet til å ruse meg igjen. Den siste gangen fikk jeg ikke slike tanker i det hele tatt og har klart å holde meg rusfri siden.»

\section{Rusmiddelbruken hadde ulike formål}

Deltakerne i studien ruset seg hovedsakelig for å håndtere vanskelige følelser og plagsomme symptomer på en alvorlig psykisk lidelse. De samme rusmidlene ble brukt til ulike formål for ulike personer.

For eksempel ble amfetamin brukt som et beroligende middel i forbindelse med plagsomme indre stemmer, for å kompensere for emosjonell avflating og som et slankemiddel. Deltakerne som uttalte dette, hadde en psykoselidelse.

Funnene fra studien støtter den tradisjonelle selvmedisineringshypotesen (11) fordi spesifikke rusmidler ble brukt for å håndtere plagsomme symptomer, ubehagelige følelser eller dysfori.

Disse funnene avviker imidlertid fra andre studier som har unders $\varnothing \mathrm{kt}$ pasientenes perspektiver, der det kom frem at bruk av rusmidler hovedsakelig hadde en negativ effekt på psykoselidelsen $(12,13)$. Det er imidlertid uklart hva som er plagsomme symptomer, ubehagelige følelser og dysfori (14).

\section{Få hadde negative erfaringer med rus}

Det som skiller funnene i de ovennevnte studiene fra denne studien, er at deltakerne primært hadde en ruslidelse, mens deltakerne i denne studien hadde utviklet en psykoselidelse over flere år med påfølgende rusmisbruk.

Et annet viktig aspekt kan være at flertallet av deltakerne i denne studien rapporterte få negative erfaringer med bruk av rusmidler, antakelig fordi de fleste av dem ikke hadde utviklet avhengighet.

\section{«Deltakerne vektla å ta det riktige rusmiddelet på riktig måte for å redusere skadelige effekter.»}

Et annet fremtredende funn i denne studien var at deltakerne vektla å ta det riktige rusmiddelet på riktig måte for å redusere skadelige effekter. I så henseende var amfetamin det hyppigst benyttede rusmiddelet. 
Forskningslitteraturen sier lite om hvordan utbredelsen av amfetamin og andre stimulerende midler er blant personer med psykoselidelser, og hvordan midlene brukes.

Det er få studier som omhandler hvordan personer med psykoselidelser bruker og erfarer virkningen av slike rusmidler, selv om det finnes eldre studier som har funnet at personer med schizofreni har lettere for å utvikle aktiv psykose ved bruk av stimulerende midler enn personer med andre psykiske lidelser (15).

\section{De færreste klarte å bli rusfrie}

Få deltakere i denne studien hadde klart å bli rusfrie. En mulig forklaring er at de fleste av dem, som tidligere nevnt, ikke hadde utviklet avhengighet og heller ikke ruset seg daglig. Mange hadde derfor ikke opplevd alvorlige skadevirkninger av sitt rusmiddelbruk.

Noen av dem som var avholdende, og noen av dem som fortsatt ruset seg, men hadde initiert rusfrie perioder, uttalte at frykten for å bli avhengig eller psykotisk var et argument for å kutte ut rusen.

Frykt for å utvikle avhengighet som en motivasjon for avholdenhet er ikke gjenfunnet $i$ andre studier, selv om det er rapportert om negative konsekvenser av rusen som motivasjon for å bli rusfri $(12,16)$.

De overnevnte studiene skilte seg imidlertid fra denne studien ved at de omhandlet deltakere med gjennomgående tungt rusmiddelmisbruk.

\section{Støttende nettverk har stor betydning}

Mine resultater indikerer at deltakernes ruserfaringer kombinert med psykisk lidelse ga dem en bevissthet om at langsiktig eller kortsiktig avholdenhet fra rusmidler var viktig for å opprettholde stabilitet i livet.

Et hovedfunn i denne studien var at deltakerne måtte ta avstand fra sitt tidligere rusmiljø for å oppnå rusfrihet. Dette samsvarer med resultatene fra Davis og O’Neills studie, som også unders $\varnothing$ kte deltakernes strategier for å bli rusfrie (17).

Andre kvalitative studier med utvalg som ikke var direkte sammenliknbare med denne studien, identifiserte imidlertid ikke avstand som strategi for å bli rusfri (16, $18,19)$. 
Flere av deltakerne i denne studien viste til betydningen av å kutte ut rusmiddelbruken for å finne en partner og komme ut av isolasjonen. Betydningen av et støttende sosialt nettverk var fremtredende, og til en viss grad ble behandlere i ACT ansett som en del av nettverket.

En gradvis bevisstgjøring om at rusmiddelbruk kom i konflikt med et vanlig liv og personlig velbefinnende, var fremtredende hos deltakerne. Flere kvalitative studier har konkludert med at støttende nettverk hadde mest å bety for at personer med psykoselidelse kunne oppnå rusfrihet (20-22).

\section{Rusmiddelbruk ble ikke ansett som misbruk}

Henwood og medarbeideres casestudie identifiserte tre begivenheter som bidro til at personer klarte å kutte ut rusmiddelbruken: vendepunkter i livet, gradvis modning og institusjonsbehandling (18). Denne studien var sammenliknbar med min studie bortsett fra at deltakerne hadde vært rusfrie over lengre tid.

$\AA$ finne den rette balansen og gjenvinne eller opprettholde stabiliteten var viktig både for dem som fortsatt brukte rusmidler, og hadde eller ikke hadde rusfrie perioder, og for dem som hadde kuttet ut rusmidler.

\section{«Deltakerne mente at moderat bruk av alkohol og cannabis var harmløst.»}

De aktive brukerne legitimerte rusmiddelbruken mer som bruk enn misbruk. Deltakerne mente at moderat bruk av alkohol og cannabis var harmløst. Det meste av ambivalensen var knyttet til bruk av amfetamin, som flere av deltakerne hadde både gode og dårlige erfaringer med.

Ut fra funnene kan det se ut som om mennesker med psykoselidelse ofte opplever motstridende følelser knyttet til sin bruk av rusmidler (13). Samtidig kan det å bli rusfri være både besværlig og konfliktfylt (16). For mennesker både med og uten alvorlig psykisk lidelse har rusen flere ansikter.

\section{Behandlere må spørre om rusmiddelbruk}

Når det gjelder selvmedisinering, bør behandlere være oppmerksomme på at pasientene kan anvende rusmidler for å lindre symptomer på psykisk lidelse, og at spesifikke rusmidler kan brukes for å motvirke både positive og negative symptomer på psykoselidelse.

Når helsepersonell kartlegger pasientenes sykdom, er det nødvendig å spørre hver enkelt om deres bruk av rusmidler og hvilken funksjon bruken har. 
Slik kartlegging bør også ta i betraktning om rusmiddelbruken har foranlediget psykisk sykdom, eller vice versa. Nettopp det kan ha innvirkning på pasientenes syn på rusmidlenes funksjon.

\section{Hvorfor trenger pasientene rusmidler?}

Behandlere trenger å motivere brukere til å redusere rusmiddelbruken, og brukere trenger hjelp til å håndtere angst og depresjon. Hvordan man kan leve med å høre indre stemmer, blir også viktig i behandlingen.

Ved kartlegging av rusmiddelbruk er det like viktig å spørre om hvordan og hvorfor pasientene bruker rusmidler, som hvilket rusmiddel de benytter.

Ved behandling med antipsykotika bør behandlere nøye vurdere bivirkningene av medikasjonen. Noen personer med psykoselidelse synes å ha bedre livskvalitet når de bruker rusmidler enn når de er avholdende.

I noen grad kan det innebære å jobbe sammen med brukerne for å minimere snarere enn å eliminere rusmiddelbruken, og behandlere bør i større grad være bevisst på slike forhold.

\section{Referanser}

1. Hartz S, Pato C, Medeiros H, Cavazos-Reg P, Sobell J, Knowles J, et al. Comorbidity of severe psychotic disorders with measures of substance use. Jama Psychiatry. 2014;71(3):248-54. DOI: 10.1001/jamapsychiatry.2013.3726

2. Hasin D, Kilcoyne B. Comorbidity of psychiatric and substance use disorders in the United States: current issues and findings from the NESARC. Curr Opin Psychiatry. 2012;25(3):165. DOI: 10.1097/yco.obo13e3283523dcc

3. Padgett DK, Smith BT, Henwood BF, Tiderington E. Life course adversity in the lives of formerly homeless persons with serious mental illness: context and meaning. Am J Orthopsychiatry. 2012;82(3):421-3O. DOI: 10.1111/j.1939$\underline{0025.2012 .01159 \cdot x}$

4. Fredwall TE. En oppsummering av kunnskap. Pasientforløp for personer med samtidig ruslidelse og psykiske lidelse. Oppsummering nr. 10. Omsorgsbiblioteket; 2018.

5. Wagstaff C. Towards understanding the self-perception of people with psychotic illness who use illicit substances and have a history of disengagement from mental health services: qualitative research. Int J Psychiatr Nurs Res. 2007;12(3):1503-20. 
6. Landheim A, Ruud T. Evaluering av ACT-team. Sluttrapport: Nasjonal kompetansetjeneste for rus- og psykisk lidelse. Lørenskog: Akershus universitetssykehus; 2014.

7. Pettersen H, Ravndal E, Ruud T, Landheim A. Searching for sobriety: How persons with severe mental illness experience abstaining from substance use. J Addict Res Ther. 2014;5(4). DOI: 10.4172/2155-6105.1000193

8. Pettersen H, Ruud T, Ravndal E, Landheim A. Walking the fine line: Selfreported reasons for substance use in persons with severe mental illness. Int J Qual Stud Health Well-being. 2013;8:21968. DOI: 10.3402/qhw.v8io.21968

9. Pettersen H. Erfaringer med rusmiddelbruk og oppsøkende behandling hos personer med psykoselidelse. (Doktorgradsavhandling.) Oslo: Universitetet i Oslo; 2015 .

10. Malterud K. Systematic text condensation: a strategy for qualitative analysis. Scand J Public Health. 2012;40(8):795-805. DOI: 10.1177/1403494812465030

11. Khantzian E. The self-medication hypothesis of substance use disorders: a reconsideration and recent applications. Harv Rev Psychiatry. 1997;4(5):231-44. DOI: $10.3109 / 10673229709030550$

12. Charles V, Weaver T. A qualitative study of illicit and non-prescribed drug use amongst people with psychotic disorders. J Ment Health. 2010;19(1):99-106. DOI: $\underline{10.3109 / 09638230802523039}$

13. Cruce G, Øyehagen A, Nordstrøm M. Experiences of alcohol and other drugs in individuals with severe mental illness and concomitant substance use disorders. Mental health and Substance use: dual diagnosis. 2008;1(3):228-41. DOI: $\underline{10.1080 / 17523280802317404}$

14. Henwood B, Padgett D. Re-evaluating the self-medication hypothesis among the dually diagnosed. Am J Addict. 2007;16(3):160-5. DOI:

$\underline{10.1080 / 10550490701375368}$

15. Lieberman J, Kane J, Alvir J. Provocative tests with psychostimulant drugs in schizofrenia. Psychopharmacology. 1987;91(4):415-33. DOI: 10.1007/bfoo216006

16. Laudet A, Magura S, Vogel H, Knight E. Perceived reasons for substance misuse among persons with a psychiatric disorder. Am J Orthopsychiatry. 2004;74:365-75. DOI: $10.1037 / 0002-9432.74 \cdot 3 \cdot 365$ 
17. Davis KE, O'Neill SJ. A focus group analysis of relapse prevention strategies for persons with substance use and mental disorders. Psychiatr Serv. 2005;56(10):128891. DOI: 10.1176/appi.ps.56.10.1288

18. Henwood B, Padgett D, Smith B, Tiderington E. Substance abuse recovery after experiencing homelessness and mental illness: case studies of change over time. $\mathrm{J}$ Dual Diagn. 2012;8(3):238-46. DOI: 10.1080/15504263.2012.697448

19. Asher C, Gask L. Reasons for illicit drug use in people with schizophrenia: qualitative study. BMC psychiatry. 2010;10:94. DOI: 10.1186/1471-244X-10-94

20. Alverson H, Alverson M, Drake R. Social patterns of substance-use among people with dual diagnoses. Ment Health Serv Res. 2001;3(1):3-14. DOI: 10.1023/a:1010104317348

21. Gomez M, Primm A, Tzolova-Iontchev I, Perry W, Hong T, Crum R. A description of precipitants of drug use among dually diagnosed patients with chronic mental illness. Community Ment Health J. 2000;36(4):351-62.

22. Thommesen H. Hverdagsliv, selvforståelse og dobbeltdiagnose - om mennesker med uvanlige erfaringer. (Doktorgradsavhandling.) Bodø: Høgskolen i Bod $\varnothing ; 2008$.

\section{FAGUTVIKLING}

\section{Hvordan kan vi overføre kunnskap, holdninger og ferdigheter fra kurs til praksisutøvelse?}

Kursdeltakerens eget ansvar og initiativ er viktig for å få et godt læringsutbytte av et kurs. I tillegg må det forankres i ledelsen slik at den nye kunnskapen kan brukes i praksis. 
Nasjonal kompetansetjeneste for læring og mestring innen helse (NK LMH) publiserte i 2019 Håndbok for helsepedagogikk: Kunnskapsbaserte anbefalinger ved utvikling av kurs $i$ helsepedagogikk for fagpersoner og brukerrepresentanter (1). Håndboken inneholder rammeverk og anbefalinger for et kurs i helsepedagogikk.

Høsten 2019 ble dette kurset testet ut som en pilot i en større kommune i Norge, og det ble grundig evaluert i etterkant (2). Evalueringen viste at selv om kurset ble godt mottatt av kursdeltakerne, var det flere faktorer som hadde betydning for om det som deltakerne hadde lært på kurset, ble brukt i praksis i etterkant eller ikke.

Vi besluttet derfor å analysere intervjuene fra evalueringen på nytt for å se nærmere på respondentenes utsagn om hva som fremmet eller hemmet implementering av ny kunnskap i praksis. Datagrunnlaget var to fokusgruppeintervjuer og fire individuelle intervjuer, som ble gjennomført to måneder etter kurset.

I analysen sorterte vi utsagnene etter henholdsvis individuelle faktorer, kursdesign og arbeidsplassfaktorer, da forskning viser at dette er faktorer som har betydning for å kunne overføre det man lærer på kurs til en jobbkontekst (3-5). Resultatene av analysen er gjengitt i en modell basert på disse faktorene (figur 1).

Figur 1. Illustrasjon av hva som fremmer eller hemmer overføring av kunnskap, ferdigheter og holdninger - fra kursdeltakelse til praksis

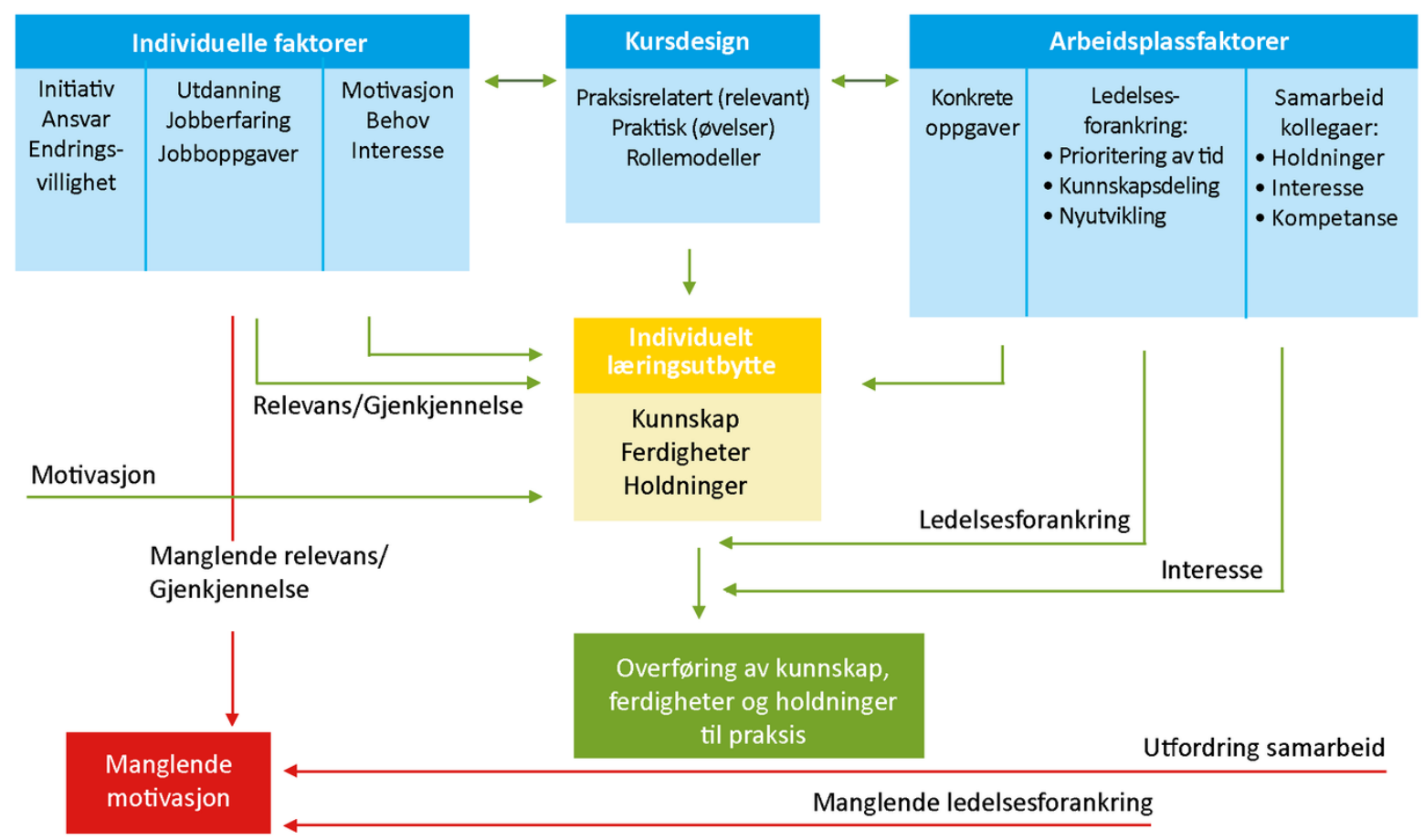




\section{Resultater}

Resultatavsnittet har vi strukturert etter modellens ulike elementer. Funnene og sammenhengen mellom dem utdyper og forklarer vi nærmere under hvert element.

\section{Deltakeren må ha individuelt læringsutbytte}

At den enkelte deltakeren har et faktisk læringsutbytte av kurset, er en forutsetning for at deltakelsen skal kunne medføre endringer i praksisutøvelsen i etterkant. Læringsutbyttet er blant annet avhengig av individuelle faktorer hos deltakerne, kursets design og faktorer ved arbeidsplassen.

Individuelle faktorer kan være utdanning, jobberfaring og aktuelle jobboppgaver. Dette vil ha betydning for graden av motivasjon, behov og interesse. For at kurset skal være relevant for deltakerne, må kursdesignet ta høyde for disse individuelle faktorene.

\section{Kurset må være relevant og gi gjenkjennelse}

I intervjuene ga kursdeltakerne spesielt uttrykk for at det var viktig at innholdet i kurset var praksisrelatert, at det var praktiske øvelser med mulighet for refleksjon og tilbakemelding, samt betydningen av at kurslederne fungerte som rollemodeller.

Noe som gikk igjen i deltakernes svar, var verdien av å kjenne seg igjen i temaene de diskuterte på kurset, og hvorvidt temaene var relevante for konkrete arbeidsoppgaver. Relevans og mulighet for gjenkjennelse fremhevet de som en forutsetning for å få et godt læringsutbytte:

«At kurslederen delte av egne erfaringer og brukte praksiseksempler - det er alfa omega ... Det blir på en måte mer gyldig, og man husker det veldig mye bedre [...]. Det var veldig mange praksiseksempler fra kurs og sånn, og jeg føler det er kjempespennende å høre på. [...] Og jeg er veldig enig $i$ at vi har kunnet bruke masse, men det kunne ha vært veldig artig å kunne ha hørt litt mere sånn fra praksishverdagen vår» (fokusgruppe 2 - deltaker 5).

\section{Kunnskap og holdninger må overføres til praksis}

At deltakere har hatt et faktisk læringsutbytte av et kurs, er imidlertid ikke ensbetydende med at tilegnede kunnskaper, ferdigheter og/eller holdninger blir overført til praksis. Ulike faktorer kan fremme eller hemme dette.

Faktorer ved arbeidsplassen som har betydning for motivasjonen til å endre praksis i tråd med ny læring, er blant annet konkrete relevante arbeidsoppgaver, graden av ledelsesforankring og samarbeid med kollegaer. Individuelle faktorer som kan ha betydning, er graden av initiativ, ansvar og endringsvillighet. 


\section{Ikke alle var motivert for å gå på kurs}

Ansvaret for rekrutteringen til det gjeldende kurset lå hos enhetsledere $\mathrm{i}$ kommunen. Motivasjonen for å gå på kurs var derfor ikke i første omgang et uttrykt $\varnothing$ nske eller behov hos den enkelte deltakeren.

Om deltakerne ikke ser relevansen av å delta på kurs eller ikke er endringsvillig, kan det påvirke motivasjonen for å endre praksis i etterkant. Kurset syntes imidlertid å motivere og inspirere flere, uavhengig av forutsetninger og relevante arbeidsoppgaver.

Flere av dem som hadde relevante arbeidsoppgaver, hadde begynt å bruke det de hadde lært i etterkant av kurset. Andre som oppga å ha lært mye på kurset, og i tillegg var motivert til å praktisere det, ga imidlertid uttrykk for at arbeidsrelaterte faktorer kunne påvirke motivasjonen negativt.

\section{«Flere av dem som hadde relevante arbeidsoppgaver, hadde begynt å bruke det de hadde lært, i etterkant av kurset.»}

Om det av en eller annen grunn ikke var mulig å praktisere det man hadde lært på kurset rett i etterkant, da motivasjonen var på sitt høyeste, kunne det bidra til at motivasjonen ble borte. Flere uttrykte bekymring for at det ville skje.

«Jeg har hørt at folk har blitt inspirert, og så er det selvfølgelig avhengig av hvordan man jobber, og hva man har med seg fra tidligere. For noen så er det kanskje litt mindre synlig hvordan de skal omsette det i praksis, og det handler kanskje om endringsvillighet - der er vi også forskjellige» (individuell - deltaker 1).

«Det blir fort at fem kursdager går veldig raskt, og da det er mye jobb og hverdag innimellom, så er det kanskje lett at det sklir ut litt hvis det ikke blir tatt tak i ettertid [...] så jeg håper at det ikke forsvinner. At du får $\varnothing v d$ deg på det her kontinuerlig etterpå, at det ikke blir med kurset» (fokusgruppe 1 - deltaker 2).

\section{Det kan være vanskelig å bevare entusiasmen}

Flere faktorer som kunne hemme motivasjonen for å praktisere det man hadde lært, ble løftet frem. En av faktorene som gikk igjen, var utfordringer i samarbeidet med kollegaer som ikke hadde vært på kurset.

Flere kursdeltakere ga uttrykk for at det var vanskelig å bevare entusiasmen når de kom tilbake på jobb. Det handlet blant annet om utfordringer knyttet til å formidle det de hadde lært til kollegaer som ikke hadde hatt samme kompetanseheving, og derfor ikke hadde samme kunnskaper, ferdigheter eller holdninger. 
Det å ikke ha det samme kunnskapsgrunnlaget å samarbeide ut fra trakk kursdeltakerne frem som en utfordring. Et eksempel som flere trakk frem, handlet om $\varnothing \mathrm{kt}$ bevissthet om viktigheten av brukermedvirkning i tjenesteutvikling.

Mange opplevde at de hadde store utfordringer med å formidle sin nye innsikt til kollegaer i enheter hvor dette ikke hadde høy prioritet eller var en del av praksis:

«Jeg ser nytten av at ha en brukerrepresentant med i starten av planleggingen $\mathrm{i}$ forhold til gruppeintervensjon. Men det er veldig vanskelig å få frem det i arbeidet med dem som kanskje ikke har det samme kurset. For vi fikk litt en åpenbaring på det kurset som de ikke har hatt. Og det er vanskelig å få frem det å jobbe med akkurat den biten, det at vi har sett nytten av å likestille rollene våre» (fokusgruppe 2 - deltaker 3 ).

Andre rapporterte at de hadde opplevd en generell interesse og nysgjerrighet hos kollegaene da de kom tilbake fra kurset. Dette fremmet motivasjonen til å fortelle mer og dele ny kunnskap og nye brukbare redskaper og modeller.

\section{Det kan være en fordel at flere deltar på samme kurs}

Det var stor forskjell på i hvilken grad kursdeltakerne hadde tatt ansvar for og initiativ til å imøtekomme faktorene som de opplevde som hemmende når det gjaldt formidling til kollegaer. Enkelte rapporterte å ha tatt ansvar gjennom dialog med sin egen leder.

Andre, da de ble spurt direkte, hadde ideer til ulike måter å formidle dette på som kunne la seg realisere i fremtiden, for eksempel i tilknytning til temadager eller i veiledningssituasjoner. De som hadde vært på kurset sammen med flere kollegaer fra samme enhet eller team, nevnte at det var en stor fordel og en faktor som fremmet samarbeid om å bruke det de hadde lært, i etterkant av kurset.

\section{«De som hadde vært på kurs alene, uttrykte et ønske om kompetanseheving for sine kollegaer.»}

De som hadde vært på kurs alene, uttrykte et $\varnothing$ nske om kompetanseheving for sine kollegaer, slik at de hadde samme kunnskapsgrunnlag å samarbeide ut fra.

«Jeg tar bare litt mer dialog med min leder i forhold til det og prøver. Det er fortsatt bare å kjøre på med det argumentet med å ha det (brukermedvirkning). [...] Det samme gjelder jo at vi diskuterer med lederne hvordan vi kan få formidlet den kompetansen vi har fătt. Og hvordan vi kan involvere andre. For man ser jo at det er veldig nyttig hvis flere har samme kompetanse» (fokusgruppe 1 - deltaker 1). 
«Jeg kom jo alene [på kurset] og kom tilbake og kjente at jeg var så giret, på en måte. Her er noen ting som vi kan bruke, og så snakker man litt om hva man har opplevd, og da er engasjementet kanskje ikke like stort. Så jeg tror det at å ha flere på lag og ha lest det samme og tenkt litt sammen, det gir en annen forståelse. Man kan liksom ikke komme tilbake og fortelle hva man har vært med på og klare å formidle det samme. Så at flere kan ta del og være med på kurset, det hadde hjulpet» (fokusgruppe 2 - deltaker 2).

\section{Manglende ledelsesforankring var en hemmende faktor}

Utfordringer i samarbeidet med kollegaer for å praktisere det de hadde lært, ble også koplet til manglende organisatorisk og ledelsesmessig forankring.

Deltakerne beskrev at manglende ledelsesforankring generelt var en hemmende faktor for muligheten til å praktisere det de hadde lært på kurset. Det handlet primært om manglende prioritering fra ledelsens side når det gjaldt å sette av tid til kunnskapsdeling med kollegaer og implementere ny kunnskap i praksis.

Flere opplevde at det var vanskelig å ta seg tid når det ikke ble prioritert av ledelsen, og det samtidig ble forventet at andre oppgaver skulle løses som før. Det handlet også om organisatoriske utfordringer knyttet til manglende ansvarsfordeling i nye prosjekter på tvers av enheter.

«Utfordringer med å ta det i bruk er vel kanskje det med tid og kapasitet i arbeidshverdagen. At man har mange oppgaver som skal utføres, og så er det - ja, det å få tid til å ha sett seg ned og få brukt det, da» (fokusgruppe 2 - deltaker 4).

«Det er jo viktig at vi får bruke tid på det. For hvis det er forankret i ledelsen, da vil det jo kanskje utløse at man får prioritere det og bruke det» (fokusgruppe 2 deltaker 5).

\section{«Flere opplevde at det var vanskelig å ta seg tid når det ikke ble prioritert av ledelsen.»}

Det var forskjell på hvordan de hemmende faktorene ble vurdert av kursdeltakerne. De diskuterte i hvilken grad ansvaret lå hos ledelsen alene, og hvilket ansvar som eventuelt lå hos den enkelte kursdeltakeren. Formidling til ledelsen om behovet for å bruke tid på implementering av ny kunnskap ble beskrevet som både en nødvendighet og en utfordring.

«Jeg tror det er viktig at de som gikk på kurs, får anledning til å fortelle sine ledere at det her har vi lært, og det ønsker vi å ta i bruk, og da trengs de her ting. Jeg tror det finnes en vilje til å sette av litt tid, men lederen må ofte ha konkrete bestillinger på hva som trengs. 
Det å få synliggjort hva kurset [kan] brukes til i praksis, så det kan gjentas, hvis det er ønskelig å spre det. Så det at dem som har gått på kurset, får virkelig brukt det og sagt noen ting om det, sånn at det blir tydelig at man faktisk implementerer det man har lært på kurs» (individuell - deltaker 1).

«Jeg tenker det er lettere hvis man har ledelsen med seg, så tenker jeg jo også at til sjuende og sist er det bra at du er med på å snakke det frem (henvendt til en annen fokusgruppedeltaker om viktigheten av brukermedvirkning), men det er ledelsen som har ansvaret med å få det på plass og, da, at det ikke skal være ditt ansvar alene» (fokusgruppe 2 - deltaker 4 ).

\section{Oppsummering}

Flere faktorer har betydning for hva som skjer i praksis etter deltakelse på kurs. Individuelt læringsutbytte, personlig ansvar og initiativ sammen med forhold ved arbeidsplassen, inkludert god ledelsesforankring, har stor betydning.

Funnene i denne evalueringen viser at det er flere ting man bør ta stilling til på arbeidsplassen før man sender de ansatte på kurs. Først og fremst er det viktig hvem man velger å sende. Har de eller skal de ha oppgaver som relaterer seg til det som kurset handler om?

Man bør dessuten overveie om flere fra samme arbeidsplass eller avdeling skal delta sammen, da det viser seg at det er enklere å komme i gang med å bruke det man har lært om man ikke er den eneste som har gått på kurs.

Dersom det ikke er mulig, er det viktig å legge til rette for at den som har vært på kurs, får mulighet til å formidle den nye kunnskapen til kollegaer, samt skape rom for at man kan bruke ny kunnskap i jobbhverdagen.

Læringseffekten av et kurs forsterkes når det man har lært, blir prøvd ut i praksis, og vi kan først snakke om styrket kompetanse når det man har lært, vises i praktiske handlinger.

\section{Referanser}

1. Hvinden K, Henriksen A-H, Brøve HB. Håndbok i helsepedagogikk kunnskapsbaserte anbefalinger ved utvikling av kurs i helsepedagogikk for fagpersoner og brukerrepresentanter. Oslo: NK LMH; 2019. NK LMH-rapport 97882-92686-35-5.

2. Henriksen A-H. Evaluering av fem dagers kurs i helsepedagogikk. Oslo: NK LMH; 2000. NK LMH-rapport 978-82-92686-40-9. 
3. Blume BD, Ford JK, Baldwin TT, Huang JL. Transfer of training: a metaanalytic review. Journal of Management. 2010;(36):1065-105.

4. Botke JA, Jansen PGW, Svetlana N, Tims KM. Work factors influencing the transfer stages of soft skills training: a literature review. Educational Research Review. 2018;(24):130-47.

5. Lim DH, Morris ML. Influence of trainee characteristics, instructional satisfaction, and organizational climate on perceived learning and training transfer. Human Resour. 2006;(17):85-115.

FAGUTVIKLING

\section{Skal vi holde på gode medarbeidere, må vi investere i dem}

Faglig engasjement, arbeidsglede og tett oppfølging av nyansatte har bidratt til det gode arbeidsmiljøet på transplantasjonskirurgisk sengepost ved Oslo universitetssykehus.

Utdanning Fagutvikling

Transplantasjonsmedisin er en relativt ny medisinsk behandling. De første transplantasjonene i Norge skjedde i 1950-årene, men først på 1980-tallet ble det en etablert medisinsk behandling for pasienter med organsvikt.

Transplantasjonskirurgisk sengepost ved Oslo universitetssykehus (OUS), Rikshospitalet, har landsdekkende funksjon for transplantasjon av abdominale organer. Årlig gjennomføres det cirka 250 nyretransplantasjoner (av disse rundt 70 med levende giver), 100 levertransplantasjoner, 30 pankreastransplantasjoner og noen få øycelletransplantasjoner.

I tillegg gjennomføres det en rekke operasjoner for å klargjøre for fremtidig transplantasjon samt annen komplisert tumorkirurgi ved innvekst i organer og kar. 


\section{Pasientene må passes godt på}

Sengeposten har 45,8 stillingshjemler, som inkluderer ledere, fagsykepleiere, sykepleiere og en servicearbeider.

Sengeposten har en egen intermediærenhet. De fleste pasientene kommer direkte hit fra operasjonsstuene. Her gjennomføres det avansert pasientbehandling som krever tett overvåkning og høy bemanning. Koronapandemien har vist hvor viktige disse intermediærenhetene er for å avlaste intensivavdelingene (1).

Vanlig liggetid etter en ukomplisert nyretransplantasjon er en uke, der pasienten skal komme seg etter operasjonen og lære å leve som transplantert. Pasienter med andre organtransplantasjoner har lengre liggetid.

\section{«Transplantasjonskirurgisk sengepost er et ettertraktet sted å arbeide.»}

En spesiell pasientgruppe er nyredonorene, altså friske personer som gjennomgår en operasjon for at noen andre som trenger det, skal få en ny nyre. Disse pasientene må også passes godt på.

Behovet for sykepleie på posten er variert og spenner fra intermediærpasienten, som trenger overvåkning, til svært komplekse pasienter med lang liggetid som trenger hjelp til alt, til pasienter som er helt selvhjulpne.

Vi arbeider svært selvstendig og samarbeider tett med andre yrkesgrupper. Stor variasjon i arbeidsoppgaver gjør transplantasjonskirurgisk sengepost til et ettertraktet sted å arbeide.

\section{Opplæring er i fokus}

Vi er stolte av vår avdeling. Den årlige medarbeiderunders $\varnothing$ kelsen viser at vi har svært fornøyde medarbeidere år etter år. Faget, utviklingen som tilbys, og det gode arbeidsmiljøet gir mindre turnover. Femten av våre ansatte har mer enn ti års erfaring fra sengeposten, ti ansatte har over tjue, og to har hele tretti års erfaring.

Men selv med lav turnover vil vi alltid miste gode medarbeidere. Noen tar videreutdanning, noen $\varnothing$ nsker seg ut av turnusordninger, mens andre flytter. Vår erfaring er at det $i$ hovedsak er ansatte med under ti års erfaring som slutter. Hvert år blir også noen gravide og går i foreldrepermisjon.

I snitt gjøres det rundt fem nyansettelser per år. Vi har opplevd flere ganger at medarbeidere som har sluttet, vender tilbake. 
Opplæringsprogrammet vi har på sengeposten, startet på 1970-tallet. Ledelsen og fagsykepleierne har alltid prioritert opplæring og faglig engasjement høyt, noe som har bidratt til kulturen og det gode arbeidsmiljøet vi har i dag.

\section{Riktig rekruttering er avgjørende}

Rekruttering av nye sykepleiere er viktig for å forme avdelingen i ønsket retning. $\AA$ lykkes med rekruttering over tid med mange dyktige medarbeidere vil øke avdelingens attraktivitet og tiltrekningskraft (2). Det er en leders ansvar å utvikle en kultur som gir i stedet for å ta energi (3).

Oslo universitetssykehus har en «100 prosent-politikk»: Vi tilstreber at alle som $\varnothing$ nsker det, får full stilling.

Før et intervju er det viktig å definere hva vi er ute etter. Hvem som velges, har avgjørende betydning for alt fra prestasjoner til stemningen på arbeidsplassen (4). Man må ha i mente at jobben stadig er i endring, så evnen til å tilpasse seg er viktig (2).

\section{«En feilansettelse vil koste mye.»}

Det er begrenset undervisning om transplantasjon i bachelorutdanningen $\mathrm{i}$ sykepleie; det meste må derfor læres. Det viktigste ved en rekruttering er ikke kunnskapsnivået den nyansatte har, men hvordan hun eller han vil passe inn $\mathrm{i}$ arbeidsmiljøet og tilegne seg ny kunnskap. Vi ønsker arbeidsglede, fokus på læring, kunnskap og motivasjon til videre utvikling hos personalet vårt.

En nyansatt sykepleier på transplantasjonskirurgisk sengepost har et halvt års opplæring. Den nyansatte går sammen med sin kontaktsykepleier de første tre månedene og regnes ikke som arbeidskraft i den perioden. Nyansattprogrammet krever både tid og penger, og en feilansettelse vil derfor koste mye.

\section{Vi investerer $\mathrm{i}$ våre medarbeidere}

Rekrutteringsprosessen er ikke avsluttet når den nye sykepleieren blir ansatt og signerer kontrakt. Nyansattprogrammet introduserer den nyansatte for kollegaer og nye oppgaver. Det gir trygghet, lojalitet og tillit til arbeidsgiveren (2).

Det er en fordel for alle parter at det oppdages tidlig om nyansettelsen var et dårlig valg (4). På mange arbeidsplasser blir innfasingen nedprioritert (4). Feilansettelser og ansatte som bruker mer tid enn nødvendig på opplæringen, koster mer tid og penger. 
Hva gjør vi for å skape gode medarbeidere? Transplantasjonskirurgisk sengepost er en høyspesialisert avdeling med et seks måneders opplæringsprogram. Gjennom opplæringsprogrammet viser vi den nyansatte at avdelingen investerer i sine medarbeidere (2).

Opplæringsprogrammet er et standardisert program med varighet på et år. Det første halve året er mest intenst, med kurs, veiledning, klinikerdager og sjekklister. Det siste halvåret er hovedsakelig veiledning.

Hvem kontaktsykepleieren skal være, vurderes nøye. For å fremme læring og skape trygghet legges det stor vekt på en god matching og personkjemi mellom den nyansatte og kontaktsykepleieren. Det er viktig at kontaktsykepleieren er sterk der den nyansatte trenger litt ekstra veiledning.

\section{Den viktigste læringen er uformell}

En av de første dagene har fagutviklingssykepleieren en kort introduksjon om opplæringsperioden, om kurs, samtaler, følgedager og nyansattpermen. Vi forventer at den nyansatte leser all litteratur og tar alle kurs.

Denne - til tider tøffe - opplæringen gjør at de blir gode sykepleiere! De må gi seg selv tid, det tar lang tid å bli en god sykepleier, gjerne et år.

\section{«På pauserommet får den nyansatte informasjon om kultur og uskrevne regler.»}

Det er viktig at lederen og kollegaene er godt forberedt på oppstartsdagen. Dersom lederen er fraværende og kontaktsykepleieren er på kurs, kan det gi et negativt førsteinntrykk. Den første dagen går med til å orientere den nyansatte, hilse på nye kollegaer, se avdelingen og bli kjent med systemene.

Breaking-in-fasen regnes gjerne som de første hundre dagene. I denne perioden kommer også gjerne virkelighetssjokket som mange kan kjenne på i startfasen. Etter en tid glir man over i settling-in-fasen, hvor man blir et etablert medlem av kollegiet (4). På avdelingen oppgir de ansatte at det kan ta så mye som tre år før de anser seg som over i den fasen.

Den viktigste læringen og tilpasningen foregår uformelt sammen med kollegaer. Den nyansatte får informasjon, utvikler kunnskap, lærer å utføre oppgaver, gjør vurderinger og utvikler holdninger. Taus kunnskap spres i hovedsak gjennom å jobbe med andre. På pauserommet får den nyansatte informasjon om kultur og uskrevne regler (4). 
Det viktigste sosialiseringstiltaket er ikke kursing, men hvem den nyansatte jobber sammen med. Gjennom spørsmål, refleksjon, diskusjon, tilbakemelding og støtte skal den nyansatte finne sin nye rolle (4).

\section{Opplæringsprogrammet}

Den nyansatte og kontaktsykepleieren går de samme vaktene minst i de første tre månedene, og helst de første seks månedene. De første månedene regnes de som en. Etter hvert får den nyansatte mer ansvar og går mer alene. Det gjøres individuelle endringer ved behov.

Opplæringsprogrammet følger OUS’ Klinisk kompetanseprogram helsefag (6). Programmet er lagt inn i Kompetanseportalen. Leder, fagansvarlig og den nyansatte har oversikt over utviklingsløpet. I Kompetanseportalen ligger alle obligatoriske kurs som skal gjennomføres årlig.

Dette gjør vårt opplæringsprogram unikt:

\section{Samtaler}

Seksjonslederen, fagutviklingssykepleieren, kontaktsykepleieren og den nyansatte har tre samtaler:

- etter en måned: målsamtalen. Den nyansatte har på forhånd skrevet hvilke mål vedkommende har for opplæringsperioden. Jo mer konkrete mål, desto bedre

- etter tre måneder: halvevaluering som går gjennom hvor langt den nyansatte har kommet, og hva som blir viktig i fortsettelsen

- etter seks måneder: sluttevaluering for å se at den nyansatte har kommet seg gjennom alle målene

\section{Ny-til-ny-coach}

Selv om man har gjort en glimrende ansettelse som tilfredsstiller alle krav og forventninger, blir ikke den nyansatte et effektivt og fullverdig medlem av kollegiet fra første dag (4). Vi har erfart at selv om vi forberedte de nyansatte på at det kan være tøft å være ny, at de må senke forventningene til seg selv og gi seg tid til å bli «varme i trøya», opplever de likevel ofte den første perioden som overveldende.

\section{«Det kan være vanskelig å snakke med en leder eller kontaktsykepleieren om hvordan opplæringen oppleves.»}

Vår erfaring er at det kan være vanskelig å snakke med en leder eller kontaktsykepleieren om hvordan opplæringen oppleves. Det var bakgrunnen for ordningen med ny-til-ny-coach, hvor den nyansatte og den som var nyansatt sist, møtes for en samtale om erfaringer og for å dele tips og triks. 
Den nyansatte får innblikk i den andres nyansattopplevelse og får støtte av en kollega, mens den andre opplever økt selvtillit og mestringsfølelse av å kunne dele av sin erfaring.

\section{Sjekkliste}

I nyansattperioden har den nyansatte en sjekkliste som gjennomgås med kontaktsykepleieren. Sjekklisten er en detaljert oversikt over blant annet aktuelle unders $\varnothing$ kelser, medisiner, rejeksjonsbehandling og tiltak ved akutte situasjoner. Hensikten med gjennomgangen er å sikre den nyansattes kunnskap om posten.

\section{Klinikerdager}

Opplæringsprogrammet er standardisert. Fagutviklingssykepleieren planlegger opplæringen før den nyansatte begynner.

Det er tre klinikerdager hvor den nyansatte går sammen med fagutviklingssykepleieren. Den nyansatte velger ut hvilke pasienter og hvilke fokusområder hun eller han ønsker veiledning om i disse dagene. Meningen er å få den nyansatte til å reflektere over det vedkommende gjør, samtidig som fagutviklingssykepleieren får et bedre bilde av hvordan hun eller han fungerer i avdelingen.

- Dag 1 kommer etter omtrent en måned og er gjerne en kveldsvakt på intermediærrommet.

- Dag 2 kommer etter tre måneder og handler om opplæringen av pasientene. Pasientinformasjonen «Veien videre» og hvordan undervisning dokumenteres i pasientjournalen, gjennomgås.

Først har fagutviklingssykepleieren opplæring med en pasient mens den nyansatte følger med. Deretter er det den nyansatte som har opplæring med den neste pasienten mens fagutviklingssykepleieren observerer.

- Dag 3 kommer når den nyansatte har gått tre-fire uker alene.

\section{Andre faste poster på programmet}

- «Tankevekkere» er en serie med faste spørsmål som den nyansatte forbereder seg på, og som gjennomgås sammen med fagutviklingssykepleieren. Jo bedre forberedt den nyansatte er, desto bedre utbytte får vedkommende. Eksempler på tankevekker-spørsmål:

Hvilke tanker gjør du deg om hva som er viktig å ta opp i innkomstsamtalen med en nyredonor? 
med avdød giver. Hva gjør du? Hva er spesielt med pankreas og lever i en slik situasjon?

- Etter fire-fem måneder følger den nyansatte en sekretær en dag og servicemedarbeideren en halv dag for å lære mer om helheten på posten og andre yrkesgrupper.

Den nyansatte får også være med på operasjon, en nyretransplantasjon med en levende giver. Den nyansatte følger først nyredonoren og ser på uttak av nyren, og følger deretter med nyren og ser på innsetting av nyren hos mottakeren.

- De tre første månedene går den nyansatte, sammen med kontaktsykepleieren, fire eller fem kvelder på intermediærstuen. Hit kommer nyre- og pankreastransplanterte rett fra operasjon.

- Hvert halvår skal den nyansatte skrive to refleksjonsnotater. Den nyansatte blir oppfordret til å skrive om både vanskelige og positive opplevelser.

De positive bes hun eller han om å reflektere rundt: «Hvorfor ble dette en så fin dag?» Refleksjonsnotatet gjennomgås med kontakt- eller fagutviklingssykepleieren.

- Mot slutten av opplæringsperioden får den nyansatte teamlederopplæring med kontaktsykepleieren kveld-dag to til tre ganger. Det innebærer å ha ansvar for alle pasientene, være med på previsitt og gå visitter med kirurgene, og å fordele arbeidsoppgaver.

Teamlederen har ansvaret for avdelingen, drift og bemanning når lederen ikke er til stede på kvelds-, natte-, helge- og helligdagsvakter.

- Det arrangeres fire veiledningsdager, hvorav en halv dag er fordypning $\mathrm{i}$ litteratur og den andre halvdelen er satt av til veiledning. Fagutviklingssykepleieren leder disse veiledningene.

Vi tilstreber å ha fire-fem nyansatte i hver gruppe for å få et godt diskusjonsforum. På forhånd får de tilsendt temaet for veiledningen med litteraturtips. 


\section{Postens kurs}

I tillegg til obligatoriske kurs i regi av Oslo universitetssykehus har vi utviklet et eget kurs. Dette går over to dager og er rettet inn mot våre pasienter. Leger og sykepleiere fra posten foreleser, i tillegg til transplantasjonskoordinator, koordinerende sykepleier for levende givere og representanter fra medisinskteknisk utstyr.

Disse dagene har både teori og anatomi i tillegg til praktisk gjennomgang av det mest sentrale medisinsk-tekniske utstyret. De nyansatte får trykke på infusjonspumper, sprøytepumper, skop og liknende.

\section{Nyansattpermen}

Den nyansatte får en perm med mye informasjon. Permen inneholder alt fra praktisk informasjon om døgnrytmen på posten til pasientinformasjonspermen «Veien videre» og en litteraturliste med relevante fagartikler. Her står også oversikter over datoer for kommende aktiviteter. Litteraturlisten er laget sammen med nyre- og gastromedisinsk sengepost og er delt inn i forskjellige organer og forskjellige sykepleiefokus.

Vi forventer at den nyansatte leser all litteratur. Vår erfaring er at litteraturen leses i løpet av det første året.

\section{Turnus er et nødvendig onde}

Forskning viser at turnusarbeid er skadelig, spesielt på lang sikt (7). Samtidig er det ikke mulig å drive døgnkontinuerlig drift uten turnusarbeid. Utfordringen er å få turnusen til å være så gunstig som mulig for den enkeltes behov og helse.

Vi har fleksiturnus, der hver medarbeider har stor innflytelse på egen turnus. Mye av ansvaret ligger dermed på den enkelte ansatte - innenfor lovens rammer. Vi har mye oppmerksomhet på helse og turnus, og har undervisning og turnussamtaler med alle ansatte. Verneombudet er involvert og går gjennom alles turnus, og kommer med råd og veiledning.

Mange av de ansatte er unge og spreke, og selv om de ikke synes det er noe problem med tett vaktoppsett, mye kveld-dag og lite hviletid, opplyses de om at dette kan være negativt på sikt.

\section{Hvordan holder vi på gode medarbeidere?}

Dagens arbeidsliv preges av stadige endringer, og folk er kompetente og opptatt av sine karrierer. De ansattes forventninger om personlig og profesjonell utvikling kan by på utfordringer for arbeidsgivere (8). For ledere blir det vanskelig å veie tilbud om utvikling til de ansatte opp mot hva arbeidsplassen får igjen for det. 
Oslo universitetssykehus har opplevd at sykepleiere får dekket videreutdanning, men at de etter endt utdanning og bindingstid bytter arbeidsplass.

Forskningsmiljøene $\varnothing$ nsker $\varnothing \mathrm{kt}$ masterkompetanse inn i sykehuset, gjerne med stillinger som er delt mellom fag/forskning og pasientnær behandling.

\section{«Vi må investere videre!»}

Det kommer ikke mer ressurser eller nye stillingshjemler, så hvem skal arbeide pasientnært mens de ansatte videreutdanner seg?

Medarbeidere slutter hos oss som regel fordi de skal flytte hjem eller ta videreutdannelse. Majoriteten søker seg til operasjon, intensiv eller helsesykepleier.

I 2019 startet vi en prosess for fagutvikling og videreutdannelse, for å beholde medarbeidere vi har lagt mye energi og midler i. Vi må investere videre!

Forsker Marit Helen Andersen har vært en sterk pådriver i denne prosessen. Hun har tidligere sørget for at flere sykepleiere har kommet gjennom både doktorgradsog masterprogram:

- En fagsykepleier startet doktorgrad høsten 2019.

- En annen fagsykepleier disputerte høsten 2020.

- En sykepleier startet masterprogram i sykepleievitenskap.

- Lederen startet master i verdibasert ledelse høsten 2019.

- En sykepleier startet på videreutdanning i nyresykepleie i 2020.

- To sykepleiere har tatt 10 studiepoeng i veiledning.

- En sykepleier har 15 studiepoeng i kunnskapsbasert praksis.

- Flere sykepleiere går klinisk spesialist-programmet.

Ved studiestart inngås det en kontrakt, hvor ledelsen forplikter seg til å tilrettelegge for og betale studiet mot en bindingstid ved avdelingen samt at temaet for masteroppgaven velges i samråd med fagutviklingssykepleieren og ledelse.

\section{Faglig nysgjerrighet smitter}

Så hvorfor vil vi alt dette? Det er viktig å bevare dyktige og faglig engasjerte medarbeidere ved at de får utvikle seg videre hos oss. Vi ønsker å få hele faget opp og frem. Vi er en avdeling med nasjonal funksjon, og vi har et ansvar for forskning og utvikling, både i Norge og internasjonalt. 
Norge er et lite land, men som transplantasjonssenter er vår avdeling ganske stor. Avdelingen har satset stort på forskning gjort av sykepleiere. Både Marit Helen Andersen, Käthe Meyer, Kjersti Lønning og Kari Gire Dahl har skrevet sine avhandlinger innen transplantasjonsfeltet, og alle arbeider fortsatt ved avdeling for transplantasjonsmedisin.

\section{«Det er lederens ansvar å utvikle en kultur og et arbeidsmiljø som hindrer hjemlengselen.»}

I januar 2021 ble det opprettet et helsefaglig forskningssenter ved avdeling for transplantasjonsmedisin for å arbeide systematisk med kompetanseutvikling og forskning i vårt miljø.

Hva gjøres for at vi ikke skal miste kompetansen? Dette er en utfordring vi må jobbe videre med. Noen aspekter av denne utfordringen synes vanskelige, som at enkelte flytter hjem. Det er lederens ansvar å utvikle en kultur og et arbeidsmiljø som hindrer hjemlengselen (9). Engasjement og faglig nysgjerrighet smitter og blir en del av kulturen.

\section{Moderne sykepleiere vil opp og frem}

Å investere i god opplæring er et gode for posten når sykepleierne arbeider her. Når de slutter her og begynner på andre avdelinger eller andre sykehus, har de med seg en kompetanse som er nyttig i all sykepleie. God opplæring er en god investering for samfunnet.

Konklusjonen er at satsing på arbeidsmiljø, god rekruttering, god opplæring, faglige utfordringer, variasjon og utviklingsmuligheter er suksessfaktorer for en god arbeidsplass - det kommer både den enkelte medarbeideren, arbeidsgiveren og pasientene til gode.

Vi ser at moderne sykepleiere vil opp og frem. Snittet for å komme inn på bachelor i sykepleie $\varnothing$ ker, og med det kommer mer karrierelystne ansatte. Om vi ikke skal miste sykepleiere til annen videreutdanning, må vi sette inn tiltak for å bevare dem i transplantasjonsmiljøet.

Vi er nå i gang med å utvikle et kompetanseprogram for erfarne sykepleiere. Dette programmet skal bestå av undervisningsdager, hospitering, relevant litteratur og en avsluttende eksamen.

Programmet skal etter planen tilbys sykepleiere med mer enn tre års erfaring og gi den enkelte både kompetanseheving og et lønnstillegg. Sykepleierne kan på den måten bygge karriere på sengeposten. 


\section{Referanser}

1. Lutro O, Holten AR, Wæhre T, Maagaard A, Pettersen E, Berdal JE, et al. Syv infeksjonsleger: Hele helsetjenesten må fungere for å bruke intensivplassene riktig. Aftenposten, kronikk. 19. mars 2021. Tilgjengelig fra:

https://www.aftenposten.no/meninger/kronikk/i/pAKpd6/syv-infeksjonsleger-helehelsetjenesten-maa-fungere-for-aa-bruke-intens (nedlastet 19.07.2021).

2. Kuvaas B, Dysvik A. Lønnsomhet gjennom menneskelige ressurser. Evidensbasert HMR. 3. utg. Bergen: Fagbokforlaget; 2016.

3. Haver A, Stålsett G. Følelser bør brukes som et kompass i lederskap. Forskersonen.no. 2. februar 2020. Tilgjengelig fra: https://forskersonen.no/arbeidkronikk-ledelse-og-organisasjon/folelser-bor-brukes-som-et-kompass-ilederskap/1631422 (nedlastet 19.07.2021).

4. Haaland FH. Å knytte bånd. Oslo: Gyldendal; 2019.

5. $\quad$ Lai L. Strategisk kompetanseledelse. Oslo: Vigmostad \& Bjørke; 2013.

6. Høghaug G. Klinisk kompetanseprogram helsefag. Oslo universitetssykehus. Tilgjengelig fra: https://ehandboken.ous-hf.no/document/26330 (nedlastet 16.09.2021).

7. Kleiven M. Tåler vi turnus? Erfaringer og anbefalinger om turnus og helse. Oslo: Norsk Sykepleierforbund; 2017. Tilgjengelig fra: https:/www.nsf.no/sites/default/files/inlineimages/hNQmuc7hzFrPtlDa4MYUCNBSnwZttcO8i1VCPokHeNZF1FxOxS.pdf (nedlastet 19.07.2021).

8. Skogstad A. Den psykologiske kontrakt mellom arbeidstaker og arbeidsgiver. I: Einarsen S, Skogstad A, red. Den dyktige medarbeider. Behov og forventninger. Bergen: Fagbokforlaget; 2005.

9. Gundersen M-BS. Sengepost som varig arbeidsplass for sykepleiere - en lederutfordring? Hvorfor slutter sykepleiere i jobben sin på sengepost på sykehus? [masteroppgave]. Bergen: Universitetet i Bergen, Det medisinske fakultet; 2018. 